\title{
Effect of pepsin-treated bovine and goat caseinomacropeptide on Escherichia coli and Lactobacillus rhamnosus in acidic conditions
}

\author{
G. Robitaille, ${ }^{1}$ C. Lapointe, D. Leclerc, and M. Britten \\ Food Research and Development Centre (FRDC), Agriculture and Agri-Food Canada, St. Hyacinthe, Quebec, Canada, J2S 8E3
}

\begin{abstract}
Caseinomacropeptide (CMP) is a 7-kDa phosphoglycopolypeptide released from $\kappa$-casein during milk digestion and in the cheesemaking process. The objective of the study was to analyze the effect of pepsintreated CMP from cow and goat milk on the resistance of Escherichia coli and Lactobacillus rhamnosus during acid stress. Bacterial cells in the exponential growth phase were suspended in acidified phosphate buffered saline with or without pepsin-treated CMP. Viability was determined during a 90-min incubation period. Pepsin-treated CMP exhibited bactericidal activity at $\mathrm{pH} 3.5$ when added in a dose-dependent manner to $E$. coli, decreasing survival by more than $90 \%$ within $15 \mathrm{~min}$ at $0.25 \mathrm{mg} / \mathrm{mL}$. At $\mathrm{pH}>4.5$, the bactericidal activity disappeared, indicating that pepsin-treated CMP was efficient at low $\mathrm{pH}$ only. The effectiveness of pepsin-treated CMP at $\mathrm{pH} 3.5$ was not affected by the presence of glycoconjugates linked to CMP or by the bovine or caprine origin of milk. In contrast, $L$. rhamnosus, a probiotic, was more resistant to acid stress when pepsin-treated bovine or caprine CMP was added to the media. Viability reached $50 \%$ after $60 \mathrm{~min}$ of incubation at $\mathrm{pH} 3$ compared with $5 \%$ survival in the media without added pepsin-treated CMP. Neither glycosylation extent nor sequence variations between CMP from bovine milk and caprine milk affected the protective activity of hydrolyzed CMP toward L. rhamnosus. This suggests that encrypted bioactive peptides released by the pepsin treatment of CMP had an antibacterial effect on $E$. coli in acidic media, but improved the resistance of L. rhamnosus to acid stress. The peptide fragment accountable for bactericidal activity is the N-terminal region $\kappa$-casein $f(106-124)$.
\end{abstract}

Key words: caseinomacropeptide, acid stress, Escherichia coli, Lactobacillus rhamnosus

Received December 31, 2010.

Accepted September 25, 2011.

${ }^{1}$ Corresponding author: robitaillegi@agr.gc.ca

\section{INTRODUCTION}

Milk is a complete food, supplying nutrients for neonates as well as bioactive compounds, supporting the development and integrity of the intestinal mucosa and the establishment of adequate gut microflora, and providing natural defenses against pathogens. Besides the known antimicrobial compounds such as lysozyme, lactoperoxidase, and lactoferrin, there are antimicrobial peptides (AMP). Antimicrobial peptides are small amphiphilic peptides, usually cationic, which can integrate membrane bilayers to form pores that kill bacteria (Brogden, 2005). They are produced by the organism itself (e.g., $\alpha$ - and $\beta$-defensins), or are released from food-derived proteins by digestive enzymes (e.g., from milk proteins). Within the human gastrointestinal tract, AMP can assist innate immunity against pathogens along with gastric acidity, digestive enzymes, peristalsis, and the mucus layer. For neonates, who have an incomplete repertoire of intestinal microflora, protection by milk-derived AMP appears to be essential for healthy gut development, including intestinal epithelial homeostasis and mucosal healing (Bu et al., 2007). Because milk-derived AMP can be generally recognized as safe (GRAS), their use as a supplement in functional foods is an interesting alternative to the use of antibiotics (Benkerroum, 2010). Several milk-derived AMP have been reported from lactoferrin, $\alpha-\mathrm{LA}$, and $\beta-\mathrm{LG}$, and from $\alpha_{\mathrm{S1}^{-}}, \alpha_{\mathrm{S}^{-}}, \beta-$, and $\kappa$-CN (López-Expósito et al., 2008; Korhonen, 2009; Tidona et al., 2009; Benkerroum, 2010 for reviews).

Caseinomacropeptide (CMP) is a 7-kDa glycolphosphopolypeptide fragment produced by initial pepsin hydrolysis of $\kappa-\mathrm{CN}$. It is also released from $\kappa$-CN into whey during chymosin-induced renneting of casein micelles in the cheesemaking process (Farrell et al., 2004). Bovine $\mathrm{\kappa}-\mathrm{CN}$ is heterogeneous, presenting several molecular variations all located within the CMP portion of $\kappa-\mathrm{CN}$, including genetic variants and post-translational glycovariants. The 2 most frequent genetic variants, A and B, are characterized by substitution ${ }^{136} \mathrm{Thr} \rightarrow{ }^{136} \mathrm{Ile}$ and ${ }^{148} \mathrm{Asp} \rightarrow{ }^{148} \mathrm{Ala}$. Up to $6 \mathrm{O}$-glycosylation sites and 5 different oligosaccharides having $N$-acetylneuraminic acid as terminal sugar, can be found. Bovine CMP is 
ROBITAILLE ET AL.

a mixture of up to 14 glycovariants (gCMP) and a nonglycosylated form (aCMP); about $50 \%$ of bovine CMP are O-glycosylated (Mollé and Léonil, 2005). Caseinomacropeptide from goat milk differs significantly from bovine CMP by 19 AA substitutions and insertion of $2 \mathrm{AA}$, mainly located in the second half of the polypeptide. The extent of $O$-glycosylation of caprine CMP reaches only $30 \%$, and $N$-glycolylneuraminic acid can also act as terminal sugar in addition to $\mathrm{N}$ acetylneuraminic acid (Moreno et al., 2001). The vast majority of nonglycosylated isoforms of caprine CMP are diphosphorylated (Rasmussen et al., 1997), whereas bovine CMP is monophosphorylated. The differences between bovine CMP and caprine CMP can be highly informative when functional properties of CMP have to be analyzed.

Caseinomacropeptide is believed to have several local and systemic biological properties affecting the digestive, immune, cardiovascular, and nervous systems (Thomä-Worringer et al., 2006). It is reported that, when CMP is used as a food supplement, it can regulate microbiota and prevent infections (Brück et al., 2003, 2006a,b), decrease blood pressure (Miguel et al., 2007), and act on gastric hormones (Yvon et al., 1994). The in vitro approaches effectively indicate that CMP and CMP-derived peptides have immunostimulating ( $\mathrm{Li}$ and Mine, 2004), antiadhesive (Neeser et al., 1988; Kawasaki et al., 2000), antihypertensive (Manso et al., 2002), antithrombotic (Jollès et al., 1986), opioid antagonism (Chiba et al., 1989), and antioxidative activities (López-Expósito et al., 2006). Furthermore, in vitro CMP and CMP-derived peptides have dual activity toward bacteria, depending on the species: growthpromoting activity in the case of Bifidobacterium genus (Azuma et al., 1984) and antimicrobial activity against several gram-positive and gram-negative species. For instance, Malkoski et al. (2001) reported antibacterial activity associated with kappacin, a specific isoform of bovine $\kappa$-CN peptide: the nonglycosylated phosphorylated CMP derived from $\kappa-\mathrm{CN}$ genetic variant $\mathrm{A}$. The

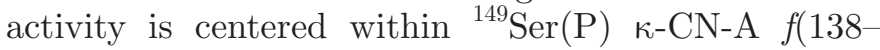
158), a peptide generated by an endoproteinase Glu-C. The bactericidal activity of kappacin varies greatly according to its molecular structure and integrity. As mentioned, only CMP from $\kappa-\mathrm{CN}-\mathrm{A}$ is active; the $\mathrm{B}$ variant is completely inactive. This is an important consideration, given that the frequency of $\kappa-\mathrm{CN}-\mathrm{B}$ is about $20 \%$. Moreover, kappacin must be nonglycosylated, which restricts the active component to a specific isoform of CMP. Finally, it has been reported that bovine CMP is extensively cleaved by pepsin within the stomach (Chabance et al., 1995, Chabance et al., 1998); the active region ${ }^{149} \mathrm{Ser}(\mathrm{P}) \kappa-\mathrm{CN}-\mathrm{A} f(138-158)$ is particularly sensitive, as it contains 5 proteolytic sites
(Mercier et al., 1972). Given all of these limitations, it is likely that the in vivo bactericidal activity kappacin is very low.

The acidic stomach environment is the first barrier against pathogens (Martinsen et al., 2005). The acidity of human stomach is dependent on food intake (type and amount) and on the time that has elapsed since the last meal. The luminal pH of around 2.0 (Dressman et al., 1990) can increase up to $\mathrm{pH} 5$ after meal ingestion (Holzapfel et al., 1998). At pH 2, Escherichia coli is rapidly killed but at $\mathrm{pH} 3.5$ the viability of $E$. coli can be higher than $50 \%$ even after 80 min of incubation (Zhu et al., 2006). Considering that gastric emptying is relatively fast, especially for liquids (Clarkston et al., 1997), the bactericidal efficiency of the stomach environment can be far from optimal. Incidentally, it is estimated that, on average, 20 to $80 \%$ of ingested $E$. coli can reach the small intestine without being inactivated by low $\mathrm{pH}$ (Takumi et al., 2000). Generation of food-derived AMP during gastric digestion could make a major contribution in terms of protecting against pathogens. On the other hand, the gastric environment can be detrimental to probiotics, bacterial stains which confer health benefits on the host when administered in adequate amounts (FAO/WHO, 2001). To be useful, food-derived AMP should be harmless for probiotics.

In all in vitro studies reporting milk-derived AMP activities, the antibacterial assays were conducted in optimal growth conditions, including neutral $\mathrm{pH}$, in liquid culture media, or on medium-rich agar, by radial diffusion. In order for a milk-derived peptide to be recognized as an efficient AMP in vivo, validation in the gastrointestinal environment is required. The aim of the present study was to investigate the effect of the biological activity of pepsin-treated CMP on the survival of $E$. coli, including $\mathrm{O} 157: \mathrm{H} 7$, and on a probiotic, Lactobacillus rhamnosus, in acidic conditions, simulating a gastric environment. Pepsin-treated bovine CMP and caprine CMP were tested to evaluate the effects of glycosylation and AA sequence variations on the biological activity of CMP.

\section{MATERIALS AND METHODS}

\section{Bacterial Strains and In Vitro Bactericidal Activity Test}

Escherichia coli O157:H7 (ATCC 43888), E. coli DH5 $\alpha$, and L. rhamnosus RW-9595 were obtained from the culture collection of the Food Research and Development Centre. Escherichia coli strains were cultured in brain heart infusion (BHI) broth at $37^{\circ} \mathrm{C}$ under aerobic conditions and L. rhamnosus was cultured anaerobically in de Man, Rogosa, and Sharpe 
(MRS) broth at $37^{\circ} \mathrm{C}$. To test bactericidal activity, an overnight bacterial culture was used to inoculate media at $1 \%$ (vol/vol). The culture was grown for $4 \mathrm{~h}$ at $37^{\circ} \mathrm{C}$ and centrifuged at $1,000 \times g$ for $5 \mathrm{~min}$ in a microcentrifuge. The bacterial pellet was washed in $0.85 \% \mathrm{NaCl}$ (wt/vol), and suspended in PBS (pH 7.0) to an optical density of 0.1 at $600 \mathrm{~nm}$. The test was carried out using a bacterial cell concentration of $10^{5}$ to $10^{6} \mathrm{cfu} / \mathrm{mL}$ for E. coli and $10^{8} \mathrm{cfu} / \mathrm{mL}$ for L. rhamnosus at $37^{\circ} \mathrm{C}$ in PBS adjusted to the appropriate $\mathrm{pH}$ and containing 0.05 to $1 \mathrm{mg} / \mathrm{mL}$ of peptides. Before use, peptides were filter-sterilized $(0.22-\mu \mathrm{m}$ filter unit; Millipore, Laval, QC, Canada). Samples were taken during incubation at $0,30,60$, and $90 \mathrm{~min}$, and viable bacterial counts $(\mathrm{cfu} / \mathrm{mL})$ were performed on Luria-Bertani broth (LB) agar for E. coli and MRS agar for L. rhamnosus using the pour plate technique. The plates were incubated at $37^{\circ} \mathrm{C}$ for $24 \mathrm{~h}$ under aerobic conditions for E. coli and anaerobic conditions for L. rhamnosus. The assays were conducted in triplicate and data from 3 independent replicate trials were analyzed using the GLM procedure (SAS Inst Inc., Cary, NC).

\section{Peptide Preparation}

Bovine milk from cows phenotyped $\kappa-\mathrm{CN}$ A was obtained from the Dairy and Swine Research and Development Centre (Agriculture and Agri-Food Canada, Sherbrooke, QC, Canada) and goat milk was from Laiterie Tournevent (Drummondville, QC, Canada). Phenotyping was carried out as described earlier (Robitaille et al., 1993). Milk was skimmed in a centrifugal separator (Elecrem3; Elecrem SA, Fresnes, France) at $35^{\circ} \mathrm{C}$. Caseins were prepared by 2 cycles of acid precipitation at $\mathrm{pH} 4.6$ with $5 \mathrm{~N} \mathrm{HCl}$ and neutralization with $5 \mathrm{~N} \mathrm{NaOH}$. Finally, caseins were solubilized at $5 \%$ (wt/ vol) at $\mathrm{pH} 6.3$ and treated with chymosin (Maxiren 180, 180,000 milk clotting units/mL; Gist Brocades France $\mathrm{SA}$, Seclin, France) at $37^{\circ} \mathrm{C}$ for $1 \mathrm{~h}$. The reaction was stopped by means of acidification $(\mathrm{pH} 4.6)$ to precipitate paracasein. The supernatant containing CMP was concentrated and diafiltered by UF (molecular weight cut-off of $10 \mathrm{kDa}$ ), and lyophilized until use. Bovine $\mathrm{CMP}$ and caprine CMP were fractionated into aCMP and gCMP using anion-exchange membrane adsorption chromatography on a $60 \mathrm{~mL}$ Mustang Q cartridge [Pall (Canada) Ltd., Mississauga, ON, Canada]. Briefly, crude CMP was dissolved at $25 \mathrm{mg} / \mathrm{mL}$ in $25 \mathrm{mM}$ Tris- $\mathrm{HCl}$ ( $\mathrm{pH} 8.0$ ) containing $6 \mathrm{M}$ urea and absorbed on the column. The fraction aCMP and gCMP were desorbed using a linear 50 to $500 \mathrm{~m} M \mathrm{NaCl}$ gradient in $25 \mathrm{~m} M$ Tris-HCl (pH 8) containing $6 M$ urea. Fractions were extensively dialyzed and lyophilized. The extent of glycosylation, based on $\mathrm{N}$-acetylneuraminic acid content, was evaluated spectrophotometrically by the acidic ninhydrin assay method (Fukuda et al., 2004). The concentration of CMP was determined using the extinction coefficient $\left(\varepsilon^{10 \mathrm{~g} / \mathrm{li}} 1 \mathrm{~cm} 214 \mathrm{~nm}\right)$ of 140 (Coolbear et al., 1996).

To prepare pepsin-treated CMP, CMP was dissolved in deionized water at $5 \mathrm{mg} / \mathrm{mL}$ and the $\mathrm{pH}$ was adjusted to 2. Pepsin (EC 3.4.23.1, 3,460 U/mg; Sigma Chemical Co., St. Louis, MO) was added (1:100 enzyme:substrate ratio) and the mixture was incubated at $37^{\circ} \mathrm{C}$ for $3 \mathrm{~h}$ under agitation. The dispersion was heated to $80^{\circ} \mathrm{C}$ for 15 min to stop the reaction, neutralized to $\mathrm{pH} 7$ by addition of $1 \mathrm{M} \mathrm{NaOH}$, and centrifuged at 16,000 $\times g$. The supernatant was recovered and lyophilized until use.

To purify the cationic peptide fraction, pepsintreated CMP was solubilized at $10 \mathrm{mg} / \mathrm{mL}$ in $10 \mathrm{mM}$ PBS (pH 7.0) at $10 \mathrm{mg} / \mathrm{mL}$ and applied on a Mustang $\mathrm{S}$ cartridge [Pall (Canada) Ltd., Mississauga, ON, Canada]. After extensive washing with the same buffer, the cationic peptide fraction was eluted with 10 $\mathrm{m} M$ phosphate ( $\mathrm{pH}$ 7.0) containing $1 M \mathrm{NaCl}$. Cationic peptides were purified by reversed-phase HPLC (RP-HPLC) using a semi-preparative $250 \times 10 \mathrm{~mm}$ column (Jupiter $10 \mu \mathrm{m}$ Proteo 90 A; Phenomenex Inc., Torrance, CA). The peptide was solubilized at $10 \mathrm{mg} /$ $\mathrm{mL}$ in $0.1 \%$ trifluoroacetic acid (TFA) and $2 \mathrm{~mL}$ were injected and eluted using a 5 to $75 \%$ linear gradient of acetonitrile in $0.1 \%$ TFA at a flow rate of $3 \mathrm{~mL} / \mathrm{min}$. The fraction containing cationic peptides was collected, evaporated under nitrogen, and lyophilized. Synthetic $\kappa-C N ~ f(106-124)$ was synthesized and purified by GenScript USA Inc. (Piscataway, NJ). All chemicals were obtained from Fisher Scientific (Nepean, ON, Canada), unless otherwise specified.

For the spiking experiments, synthetic $\kappa_{-} \mathrm{CN} f\left(106^{-}\right.$ 124) was added to pepsin-treated CMP $(0.2 \mathrm{mg} / \mathrm{mg}$ of pepsin-treated CMP) and analyzed by RP-HPLC on an ACE $5 \mathrm{C}_{18^{-}}-300$ column $(150 \times 4.6 \mathrm{~mm}$; Canadian Life Science, Peterborough, ON, Canada) using a linear gradient of 30 to $50 \%$ ( $\mathrm{vol} / \mathrm{vol}$ ) acetonitrile in $0.1 \%$ TFA at a flow rate of $1 \mathrm{~mL} / \mathrm{min}$ at $20^{\circ} \mathrm{C}$ and at $50^{\circ} \mathrm{C}$.

Sequence similarity between bovine CMP and caprine CMP was obtained using the MultAlin multiple sequence alignment program (http://npsa-pbil. ibcp.fr/cgi-bin/npsa_automat.pl?page=/NPSAHLP $/$ npsahlp_alignmultalin.html). Peptide hydrophobicity was evaluated using the ProtScale program (http:// www.expasy.org/tools/protscale.html). The net charge of the peptide over the entire $\mathrm{pH}$ range was estimated using Protein Calculator v3.3 (http://www.scripps. edu/ cdputnam/protcalc.html). 


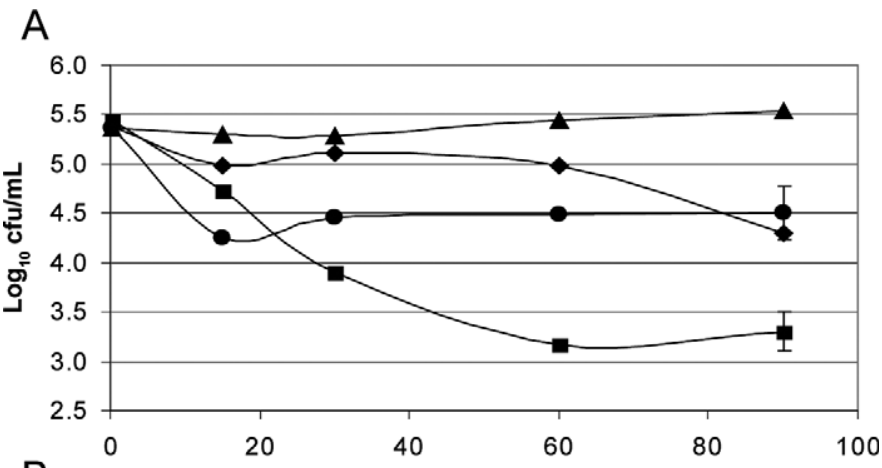

B

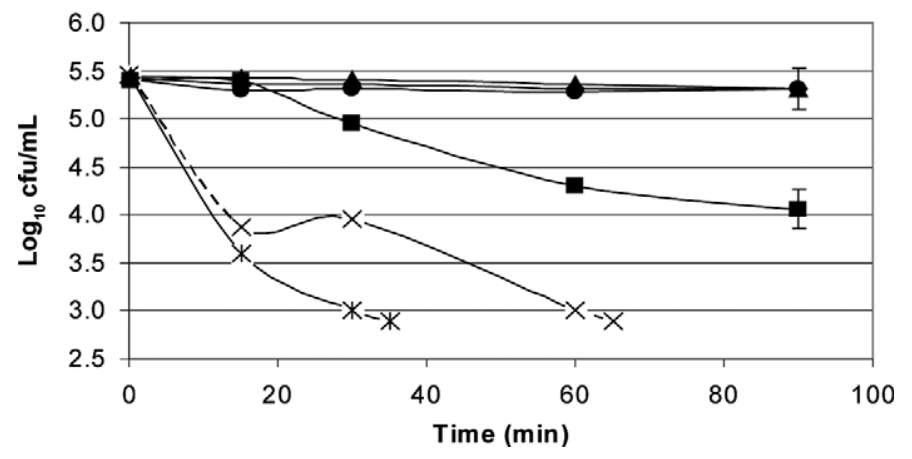

Figure 1. Survival of Escherichia coli DH5a during a 90-min incubation period in PBS with (A) or without (B) addition of $0.5 \mathrm{mg}$ / $\mathrm{mL}$ of pepsin-treated bovine caseinomacropeptide (CMP). Incubation $\mathrm{pH}$ was 2.5 (× with vertical line), $3.0(\times), 3.5(\mathbf{\square}), 4.0(\bullet), 4.5(\bullet)$, and $7(\boldsymbol{\Lambda})$. Values \pm standard errors are given for $\mathrm{pH} 3.5$ and 4 only, to simplify presentation.

\section{RESULTS AND DISCUSSION}

The tolerance of E. coli DH5 $\alpha$ to acid stress was assessed by evaluating the viability in $\mathrm{PBS}$ at $\mathrm{pH} 2.5$ to $\mathrm{pH} 7$ (Figure 1). At $\leq \mathrm{pH} 3$, viability was decreased by more than $1.5 \log _{10}$ within 15 min, whereas it took 90 min of incubation at $\mathrm{pH} 3.5$ to decrease the bacterial counts to that level. These results are similar to those reported by Zhu et al. (2006) showing that the viability of $E$. coli strains remains high after $80 \mathrm{~min}$ at $\mathrm{pH} 3.5$. At $\mathrm{pH}>4, E$. coli cell counts did not vary greatly $(P>$ 0.1 ) for at least $90 \mathrm{~min}$. This suggests a $\mathrm{pH}$ threshold between pH 3.0 and 3.5 at which E. coli becomes less sensitive to the bactericidal action of $\mathrm{pH}$.

The addition of $0.5 \mathrm{mg} / \mathrm{mL}$ of pepsin-treated CMP to the incubation media induced significant bactericidal activity $(P<0.05)$, decreasing survival by about 0.7 $\log$ within $15 \mathrm{~min}$ and $>2 \log$ within $60 \mathrm{~min}$ (Figure 1). This bactericidal effect was detected only at a low $\mathrm{pH}$ level, as the bacteria were relatively resistant to the effect of $\mathrm{pH} \geq 4.5$. Moreover, intact bovine CMP (1 $\mathrm{mg} / \mathrm{mL}$ ) did not affect the viability of $E$. coli after 90 min of incubation at $\mathrm{pH} 3.5$ (data not shown). These results indicate that, to express bactericidal activity,

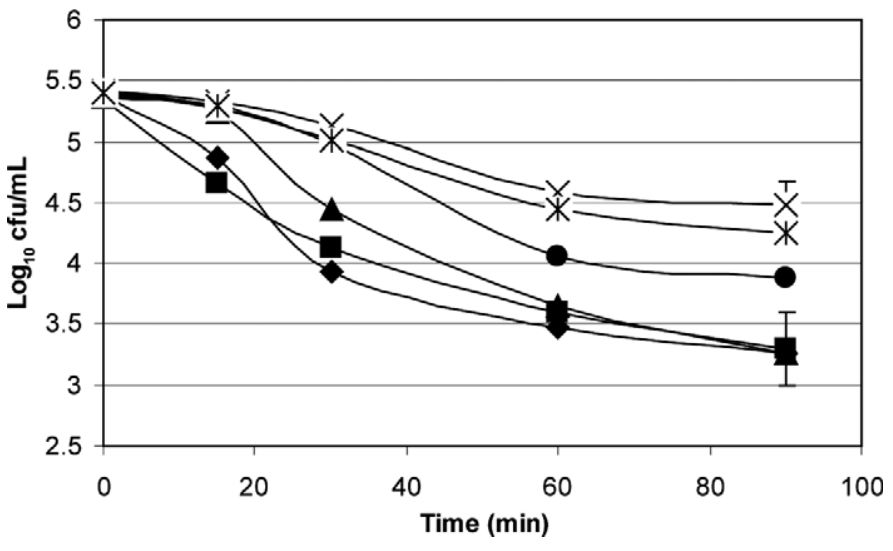

Figure 2. Survival of Escherichia coli DH5a during a 90-min incubation period in PBS at $\mathrm{pH}$ 3.5. The concentration of added pepsintreated caseinomacropeptide (CMP) was $0 \mathrm{mg} / \mathrm{mL}(\times), 0.03 \mathrm{mg} / \mathrm{mL}$ ( $\times$ with vertical line), $0.06 \mathrm{mg} / \mathrm{mL}(\bullet), 0.12 \mathrm{mg} / \mathrm{mL}(\boldsymbol{\Lambda}), 0.25 \mathrm{mg} / \mathrm{mL}$ (•), and $0.50 \mathrm{mg} / \mathrm{mL}(\mathbf{\square})$.

encrypted peptides must be released by pepsin proteolysis of bovine CMP and that this bactericidal activity is observed only under acidic conditions.

To study the dose-dependent bactericidal activity at $\mathrm{pH} 3.5$, various concentrations of pepsin-treated bovine CMP were added to the media (Figure 2). The bactericidal action of pepsin-treated bovine CMP showed an increasing trend up to $0.25 \mathrm{mg} / \mathrm{mL}$. The pathogenic strain E. coli O157:H7 has been shown to be as sensitive as E. coli DH5 $\alpha$ to pepsin-treated CMP at $\mathrm{pH} 3.5$ (data not shown).

Glycoconjugates have been found to be implicated in many biological activities such as biological recognition processes, particularly with $\mathrm{N}$-acetylneuraminic acid as the terminal sugar (Lehmann et al., 2006). To get some insight into the nature of the specific components or region of CMP that accounts for the bactericidal activity, pepsin-treated aCMP $(<0.1 \mathrm{~mol}$ of neuraminic acid $/ \mathrm{mol})$ and gCMP ( $>3.5$ moles of neuraminic acid/ mol) originating from cow and goat milk were tested. As shown in Figure 3, pepsin-treated bovine and caprine aCMP at $0.5 \mathrm{mg} / \mathrm{mL}$ decreased the viability of $E$. coli, as did pepsin-treated bovine and caprine gCMP. This demonstrated that the bactericidal activity of pepsin-treated CMP was not related to the presence of oligosaccharide side chains.

A study was also conducted to evaluate the influence of pepsin-treated bovine CMP on L. rhamnosus viability. At $\mathrm{pH} 3.0$, L. rhamnosus was sensitive to acid stress. The cell count decreased from about $1.5 \times$ $10^{8} \mathrm{cfu} / \mathrm{mL}$ to $1.5 \times 10^{6} \mathrm{cfu} / \mathrm{mL}$ after $60 \mathrm{~min}$ (Figure 4). When pepsin-treated bovine or caprine aCMP or gCMP were added at concentrations as low as $0.05 \mathrm{mg} /$ $\mathrm{mL}$, cell death was decreased by $>1.2 \log$ to reach 2.5 


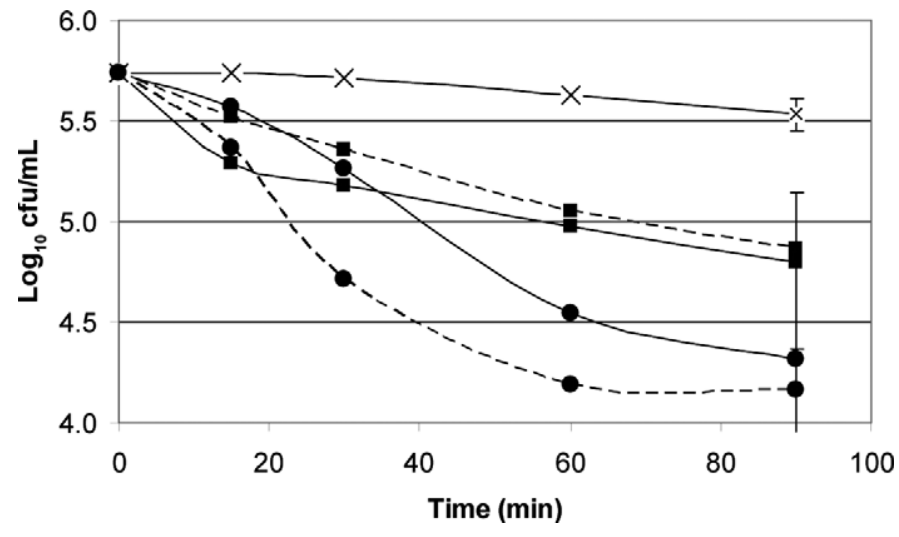

Figure 3. Effect of $O$-glycosylation on bactericidal activity of pepsin-treated caseinomacropeptide (CMP). Survival of Escherichia coli DH5 $\alpha$ during a 90-min incubation period in PBS $(\mathrm{pH} 3.5)$ without $(\times)$ or with added pepsin-treated nonglycosylated $(\mathbf{\square})$ or glycosylated $(\bullet)$ CMP $(0.5 \mathrm{mg} / \mathrm{mL})$ from bovine (solid line) and caprine (dashed line).

$\times 10^{7} \mathrm{cfu} / \mathrm{mL}$. This demonstrated that pepsin-treated CMP can protect L. rhamnosus from acid stress and that its protective effect was not affected by the extent of glycosylation or the sequence variations due to the bovine and caprine origins of CMP.

The bactericidal activity of pepsin-treated CMP is dependent on AA sequence, as shown on Figure 3. The active peptide released by pepsin should be located within a region of homology between bovine and caprine CMP. Pepsin proteolysis of bovine CMP generates 14 peptides consisting of 2 to 19 AA (Mercier et al., $1972)$. The N-terminal peptide $\kappa$-CN $f(106-124)$ is a good bactericidal candidate for several reasons. First, this region is well conserved between species (e.g., bovine, goat, human, common rorqual, pig, camel, and red deer) with identities $\geq 13 / 19$ AA, including a preserved sequence ${ }^{107} \mathrm{AIPPKKX} Q \mathrm{DLK}^{116}$ and the 3 lysines at the same positions. Second, the isoelectric point is high, ranging from 8.25 to 9.7 for the majority of species. Furthermore, the hydrophobicity profile of bovine and caprine $\mathrm{k}_{\text {-CN }} f(106-124)$ is very similar, characterized by a cationic central core surrounded by 2 hydrophobic regions. Finally, $\kappa$-CN $f(106-124)$ is proline rich, a characteristic shared by many cationic antibacterial peptides (http://aps.unmc.edu/AP/main.html). As mentioned by Shinnar et al. (2003), high proline content can improve resistance to digestion. Incidentally, it has been reported that $\kappa-\mathrm{CN} f(106-124)$ is rapidly generated within the stomach and is subsequently relatively resistant to gastric digestion (Chabance et al., 1995, 1998). This is for ensuring significant biological activity.

A synthetic peptide consisting of 19 AA encompassing $\kappa$-CN $f(106-124)$ was synthesized and tested for bactericidal activity against E. coli DH5a and $E$. coli O157:H7 (ATCC 43888). The viability of E. coli O157:H7 decreased more rapidly at $\mathrm{pH} 3.5$ in the presence of synthetic $\kappa$-CN $f(106-124)$ compared with pepsin-treated CMP (Figure 2). The cell count decreased by more than $2 \log _{10}$ within $15 \mathrm{~min}$ at $0.5 \mathrm{mg} / \mathrm{mL}$ (Figure 5) and within $45 \mathrm{~min}$ at $0.05 \mathrm{mg} / \mathrm{mL}$ (data not shown). Moreover, the bactericidal activity showed $\mathrm{pH}$ dependency similar to the pepsin-treated bovine CMP. The resistance of E. coli $\mathrm{O} 157: \mathrm{H} 7$ was relatively high at $\mathrm{pH} 4.0$ compared with $\mathrm{pH} 3.5$, decreasing by only $0.2 \log$ after $30 \mathrm{~min}$; after that, it continued to gradually decrease, eventually reaching $1.1 \log$ at $90 \mathrm{~min}$. At $\mathrm{pH} 4.5, E$. coli was resistant to acid stress, with or without synthetic $\kappa-\mathrm{CN} f(106-124)$. The loss of activity observed in the presence of the synthetic $\kappa$-casein $f(106-124)$ peptide at higher $\mathrm{pH}$ is probably due to the decrease in the cationic character of the peptide. In fact, it is estimated that an increase in $\mathrm{pH}$ from 3.5 to 6.5 decreases the net charge of $\kappa-\mathrm{CN} f(106-124)$ from +3.1 to +1 due to deprotonation of ${ }^{114} \mathrm{Asp}$ in particular. Considering that the initial step of the proposed mechanism of action of cationic AMP is electrostatic interaction between the cationic segment of AMP and negatively charged phospholipid head groups (Brogden, 2005 ), the loss of positive charges would weaken these interactions.

Reversed-phase HPLC analysis of $\kappa$-CN $f(106-124)$ and pepsin-treated bovine CMP was conducted (Figure 6 and 7$)$. At $20^{\circ} \mathrm{C}$, the synthetic $\kappa-\mathrm{CN} f(106-124)$ was resolved into 2 peaks at 27.8 and $31.6 \mathrm{~min}$ on an HPLC $\mathrm{C}_{18}$ column (Figure 6a). These 2 peaks were also found in the cationic CMP purified by cation-exchange chromatography followed by preparative RP-HPLC (Figure $6 \mathrm{~d})$. The same 2 peaks increased in relative intensity in

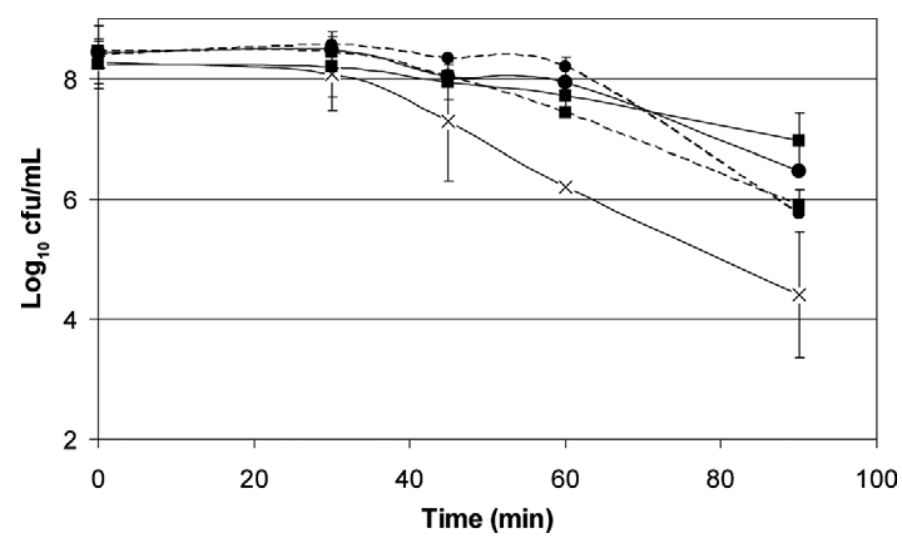

Figure 4. Effect of added pepsin-treated caseinomacropeptide (CMP) on survival of Lactobacillus rhamnosus RW-9595M during a 90-min incubation period in PBS $(\mathrm{pH} 3)$ without $(x)$ and with added pepsin-treated nonglycosylated $(\mathbf{\square})$ or glycosylated $(\bullet)$ bovine (solid line) and caprine (dashed line) CMP $(0.5 \mathrm{mg} / \mathrm{mL})$. 


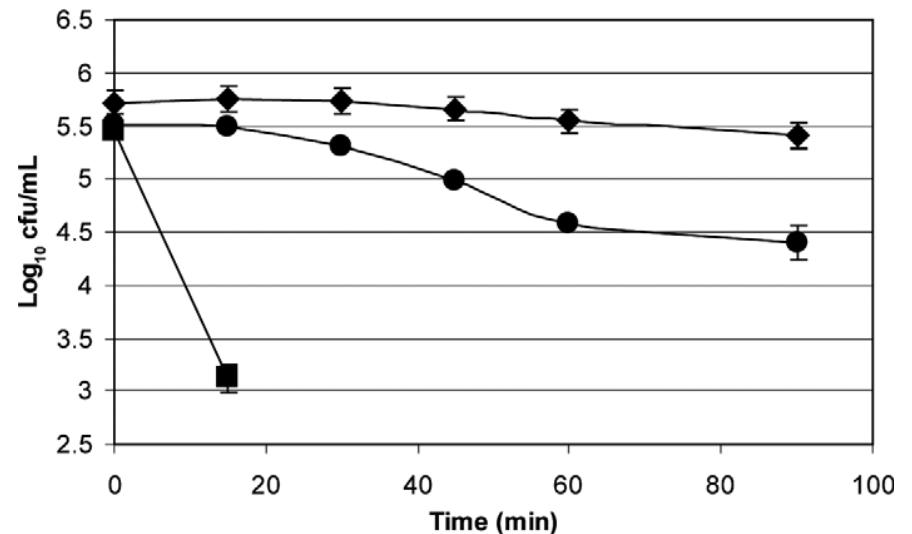

Figure 5. Survival of Escherichia coli O157:H7 during a 90-min incubation period in PBS at $\mathrm{pH} 3.5(\mathbf{\square})$ or at $\mathrm{pH} 4.0(\bullet)$ with addition of $0.5 \mathrm{mg} / \mathrm{mL}$ of synthetic $\mathrm{k}-\mathrm{CN} f(106-124)$. Control at $\mathrm{pH} 3.5$ without added peptide $(\bullet)$.

the spiked sample (Figure 6c) containing pepsin-treated CMP and synthetic k-CN $f(106-124)$.

The chromatogram from the RP-HPLC analysis of synthetic $\kappa-\mathrm{CN} f(106-124)$ at $50^{\circ} \mathrm{C}$ showed that the peptide was eluted as a broad peak with a retention time centered on 24.7 min (Figure 7a). A similar peak shape was detected at the position of pepsin-treated CMP (Figure $7 \mathrm{~b})$ in the chromatogram and in the spiked sample (Figure 7c), where it specifically increased in intensity. The elution of synthetic $\kappa-\mathrm{CN} f(106-124)$ as a doublet at $20^{\circ} \mathrm{C}$ and as a broad band at $50^{\circ} \mathrm{C}$ can be explained by the presence of prolines in tandem. It has been shown that linear peptides with a proline-proline bond show a slow conformational equilibrium that induces peak broadening or peak splitting, depending on the temperature during RP-HPLC separation (Gesquiere et al., 1989). The similarities between the

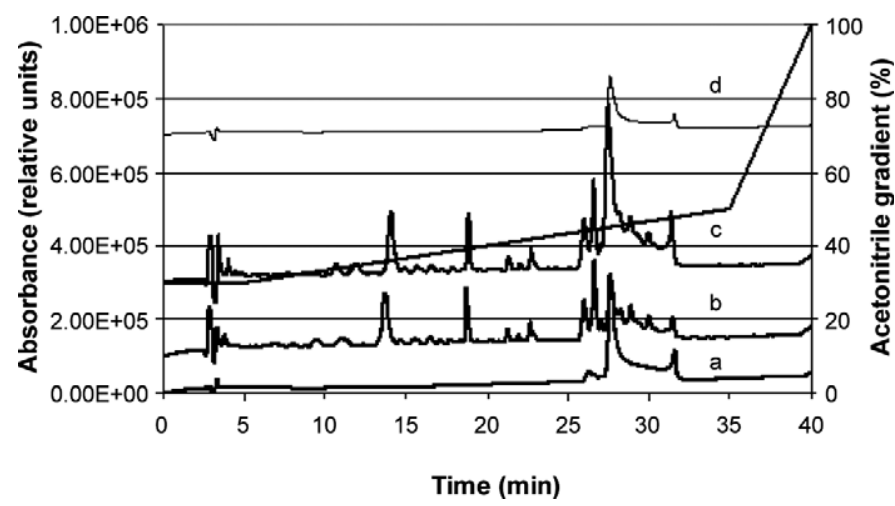

Figure 6. Reversed-phase HPLC elution profile of (a) synthetic k-CN f(106-124), (b) pepsin-treated caseinomacropeptide (CMP), (c) spiked sample, and (d) cationic CMP peptide. Linear gradient of 30 to $50 \%$ acetonitrile containing $0.1 \%$ trifluoroacetic acid (TFA) on a $\mathrm{C}_{18}$ column at $20^{\circ} \mathrm{C}$.

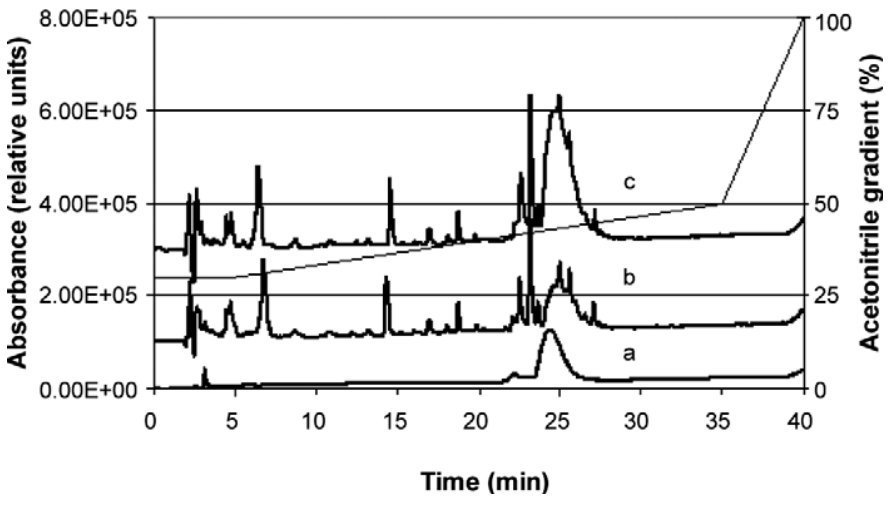

Figure 7. Reversed-phase HPLC elution profile of (a) synthetic к-CN $f(106-124)$, (b) pepsin-treated caseinomacropeptide (CMP), and (c) a spiked sample. Linear gradient of 30 to $50 \%$ acetonitrile containing $0.1 \%$ trifluoroacetic acid (TFA) on a $\mathrm{C}_{18}$ column at $50^{\circ} \mathrm{C}$.

RP-HPLC profiles of synthetic $\kappa$-CN $f(106-124)$ and the cationic CMP and its detection in pepsin-treated CMP corroborate the hypothesis that the bactericidal peptide $\kappa$-CN $f(106-124)$ is generated by pepsin hydrolysis of CMP in acidic conditions.

Besides exhibiting bactericidal activity against $E$. coli as demonstrated in this study, $\kappa$-casein $f(106-124)$ includes the fragment $\kappa$-CN $f(106-116)$, which is detected in the duodenum for several hours and then absorbed by the intestinal mucosa (Chabance et al. 1998). $k$-Casein $f(106-116)$ is antithrombotic, inhibiting ADP-induced platelet aggregation and the binding of fibrinogen to platelets (Jollès et al., 1986). This type of multifunctional role is observed with other AMP, such as lactoferricin from pepsin-treated lactoferrin, which has antimicrobial, antifungal, antitumoral, immunoregulatory (Wakabayashi et al., 2006), and antihypertensive activities (Ruiz-Giménez et al., 2010).

In conclusion, CMP is the first casein fragment produced from $\kappa$-CN during gastric digestion. Caseinomacropeptide is rapidly hydrolyzed into shorter peptides under the action of pepsin. One of these peptides, the positively charged peptide $\kappa-C N f(106-124)$, can act as an antibacterial agent against $E$. coli during the gastric phase. A systematic analysis of gram-positive and gram-negative bacteria is being carried out to evaluate the efficiency of $\kappa$-CN $f(106-124)$. Preliminary results indicate that the peptide is also active against grampositive Listeria monocytogenes.

\section{ACKNOWLEDGMENTS}

This study was supported by the Agriculture and Agri-Food Canada (Ottawa, ON, Canada) research program. 


\section{REFERENCES}

Azuma, N., K. Yamauchi, and T. Mitsuoka. 1984. Bifidus growthpromoting activity of a glycomacropeptide derived from human к-casein. Agric. Biol. Chem. 48:2159-2162.

Benkerroum, N. 2010. Antimicrobial peptides generated from milk proteins: A survey and prospects for application in the food industry. A review. Int. J. Dairy Technol. 63:320-338.

Brogden, K. A. 2005. Antimicrobial peptides: Pore formers or metabolic inhibitors in bacteria? Nat. Rev. Microbiol. 3:238-250.

Brück, W. M., S. L. Kelleher, G. R. Gibson, G. Graverholt, and B. L. Lönnerdal. 2006a. The effects of $\alpha$-lactalbumin and glycomacropeptide on the association of CaCo-2 cells by enteropathogenic Escherichia coli, Salmonella typhimurium and Shigella flexneri. FEMS Microbiol. Lett. 259:158-162.

Brück, W. M., S. L. Kelleher, G. R. Gibson, K. E. Nielsen, D. E. W. Chatterton, and B. Lönnerdal. 2003. rRNA probes used to quantify the effects of glycomacropeptide and $\alpha$-lactalbumin supplementation on the predominant groups of intestinal bacteria of infant rhesus monkeys challenged with enteropathogenic Escherichia coli. J. Pediatr. Gastroenterol. Nutr. 37:273-280.

Brück, W. M., M. Redgrave, K. M. Tuohy, B. Lönnerdal, G. Graverholt, O. Hernell, and G. R. Gibson. 2006b. Effects of bovine $\alpha$-lactalbumin and casein glycomacropeptide-enriched infant formulae on faecal microbiota in healthy term infants. J. Pediatr. Gastroenterol. Nutr. 43:673-679.

Bu, H. F., X. L. Zuo, X. Wang, M. A. Ensslin, V. Koti, W. Hsueh, A. S. Raymond, B. D. Shur, and X. D. Tan. 2007. Milk fat globule-EGF factor 8/lactadherin plays a crucial role in maintenance and repair of murine intestinal epithelium. J. Clin. Invest. 117:3673-3683.

Chabance, B., P. Jollès, C. Izquierdo, E. Mazoyer, C. Francoual, L. Drouet, and A. M. Fiat. 1995. Characterization of an antithrombotic peptide from $\kappa$-casein in newborn plasma after milk ingestion. Br. J. Nutr. 73:583-590.

Chabance, B., P. Marteau, J. C. Rambaud, D. Migliore-Samour, M. Boynard, P. Perrotin, R. Guillet, P. Jollès, and A. M. Fiat. 1998 Casein peptide release and passage to the blood in humans during digestion of milk or yogurt. Biochimie 80:155-165.

Chiba, H., F. Tani, and M. Yoshikawa. 1989. Opioid antagonist peptides derived from k-casein. J. Dairy Res. 56:363-366.

Clarkston, W. K., M. M. Pantano, J. E. Morley, M. Horowitz, J. M. Littlefield, and F. R. Burton. 1997. Evidence for the anorexia of aging: Gastrointestinal transit and hunger in healthy elderly vs. young adults. Am. J. Physiol. 272:R243-R248.

Coolbear, K. P., D. F. Elgar, and J. S. Ayers. 1996. Profiling of genetic variants of bovine $\kappa$-casein macropeptide by electrophoretic and chromatographic techniques. Int. Dairy J. 6:1055-1068.

Dressman, J. B., R. R. Berardi, L. C. Dermentzoglou, T. L. Russell, S. P. Schmaltz, J. L. Barnett, and K. M. Jarvenpaa. 1990. Upper gastrointestinal (GI) $\mathrm{pH}$ in young, healthy men and women. Pharm. Res. 7:756-761.

FAO/WHO. 2001. Health and Nutritional Properties of Probiotics in Food Including Powder Milk with Live Lactic Acid Bacteria. Food and Agriculture Organization of the United Nations, World Health Organization. http://www.who.int/entity/foodsafety/publications/fs_management/en/probiotics.pdf.

Farrell, H. M. Jr., R. Jimenez-Flores, G. T. Bleck, E. M. Brown, J. E. Butler, L. K. Creamer, C. L. Hicks, C. M. Hollar, K. F. Ng-KwaiHang, and H. E. Swaisgood. 2004. Nomenclature of the proteins of cows' milk-Sixth revision. J. Dairy Sci. 87:1641-1674.

Fukuda, S. P., S. M. Roig, and L. F. Prata. 2004. Correlation between acidic ninhydrin and HPLC methods to evaluate fraudulent addition of whey in milk. Lait 84:501-512.

Gesquiere, J. C., E. Diesis, M. T. Cung, and A. Tartar. 1989. Slow isomerization of some proline-containing peptides inducing peak splitting during reversed-phase high-performance liquid chromatography. J. Chromatogr. A 478:121-129.

Holzapfel, W. H., P. Haberer, J. Snel, U. Schillinger, and J. H. J. Huis in't Veld. 1998. Overview of gut flora and probiotics. Int. J. Food Microbiol. 41:85-101.
Jollès, P., S. Lévy-Toledano, and A. M. Fiat. 1986. Analogy between fibrinogen and casein. Effect of an undecapeptide isolated from к-casein on platelet function. Eur. J. Biochem. 158:379-382.

Kawasaki, Y., S. Tazume, K. Shimizu, H. Matsuzawa, S. Dosako, H. Isoda, M. Tsukiji, R. Fujimura, Y. Muranaka, and H. Isihida. 2000. Inhibitory effects of bovine lactoferrin on the adherence of enterotoxigenic Escherichia coli to host cells. Biosci. Biotechnol. Biochem. 64:348-354.

Korhonen, H. 2009. Milk-derived bioactive peptides: From science to applications. J. Funct. Foods 1:177-187.

Lehmann, F., E. Tiralongo, and J. Tiralongo. 2006. Sialic acid-specific lectins: Occurrence, specificity and function. Cell. Mol. Life Sci. 63:1331-1354.

Li, E. W. Y., and Y. Mine. 2004. Immunoenhancing effects of bovine glycomacropeptide and its derivatives on the proliferative response and phagocytic activities of human macrophagelike cells, U937. J. Agric. Food Chem. 52:2704-2708.

López-Expósito, I., J. Á. Gómez-Ruiz, L. Amigo, and I. Recio. 2006. Identification of antibacterial peptides from ovine $\alpha_{\mathrm{s} 2}$-casein. Int. Dairy J. 16:1072-1080.

López-Expósito, I., A. Pellegrini, L. Amigo, and I. Recio. 2008. Synergistic effect between different milk-derived peptides and proteins. J. Dairy Sci. 91:2184-2189.

Malkoski, M., S. G. Dashper, N. M. O'Brien-Simpson, G. L. Talbo, M. Macris, K. J. Cross, and E. C. Reynolds. 2001. Kappacin, a novel antibacterial peptide from bovine milk. Antimicrob. Agents Chemother. 45:2309-2315.

Manso, M. A., C. Escudero, M. Alijo, and R. López-Fandiño. 2002 Platelet aggregation inhibitory activity of bovine, ovine, and caprine $\kappa$-casein macropeptides and their tryptic hydrolysates. J. Food Prot. 65:1992-1996.

Martinsen, T. C., K. Bergh, and H. L. Waldum. 2005. Gastric juice: A barrier against infectious diseases. Basic Clin. Pharmacol. Toxicol. 96:94-102.

Mercier, J. C., J. Uro, B. Ribadeau-Dumas, and F. Grosclaude. 1972 Structure primaire du caseinomacropeptide de la caseine kappa B I bovine. Eur. J. Biochem. 27:535-547.

Miguel, M., M. A. Manso, R. López-Fandiño, M. J. Alonso, and M. Salaices. 2007. Vascular effects and antihypertensive properties of к-casein macropeptide. Int. Dairy J. 17:1473-1477.

Mollé, D., and J. Léonil. 2005. Quantitative determination of bovine $\kappa$-casein macropeptide in dairy products by liquid chromatography/electrospray coupled to mass spectrometry (LC-ESI/MS) and liquid chromatography/electrospray coupled to tandem mass spectrometry (LC-ESI/MS/MS). Int. Dairy J. 15:419-428.

Moreno, F. J., A. Olano, and M. Villamiel. 2001. $N$-acetyl-and $N$-glycolyl-neuraminic acid content in $\kappa$-casein macropeptides. Milchwissenschaft 56:669-671.

Neeser, J.-R., A. Chambaz, S. Del Vedovo, M.-J. Prigent, and B. Guggenheim. 1988. Specific and nonspecific inhibition of adhesion of oral Actinomyces and streptococci to erythrocytes and polystyrene by caseinoglycopeptide derivatives. Infect. Immun. 56:3201-3208.

Rasmussen, L. K., E. S. Sørensen, T. E. Petersen, N. C. Nielsen, and J. K. Thomsen. 1997. Characterization of phosphate sites in native ovine, caprine, and bovine casein micelles and their caseinomacropeptides: A solid-state phosphorus-31 nuclear magnetic resonance and sequence and mass spectrometric study. J. Dairy Sci. 80:607-614.

Robitaille, G., K. F. Ng-Kwai-Hang, and H. G. Monardes. 1993. Effect of $\kappa$-casein glycosylation on cheese yielding capacity and coagulating properties of milk. Food Res. Int. 26:365-369.

Ruiz-Giménez, P., A. Ibáñez, J. B. Salom, J. F. Marcos, J. J. LópezDíez, S. Vallés, G. Torregrosa, E. Alborch, and P. Manzanares. 2010. Antihypertensive properties of lactoferricin B-derived peptides. J. Agric. Food Chem. 58:6721-6727.

Shinnar, A. E., K. L. Butler, and H. J. Park. 2003. Cathelicidin family of antimicrobial peptides: Proteolytic processing and protease resistance. Bioorg. Chem. 31:425-436.

Takumi, K., R. de Jonge, and A. Havelaar. 2000. Modelling inactivation of Escherichia coli by low pH: Application to passage through 
the stomach of young and elderly people. J. Appl. Microbiol. 89:935-943.

Thomä-Worringer, C., J. Sørensen, and R. López-Fandiño. 2006. Health effects and technological features of caseinomacropeptide. Int. Dairy J. 16:1324-1333.

Tidona, F., A. Criscione, A. M. Guastella, A. Zuccaro, S. Bardonaro, and D. Marletta. 2009. Bioactive peptides in dairy products. Ital. J. Anim. Sci. 8:315-340.
Wakabayashi, H., K. Yamauchi, and M. Takase. 2006. Lactoferrin research, technology and applications. Int. Dairy J. 16:1241-1251.

Yvon, M., S. Beucher, P. Guilloteau, I. Le Huerou-Luron, and T. Corring. 1994. Effects of caseinomacropeptide (CMP) on digestion regulation. Reprod. Nutr. Dev. 34:527-537.

Zhu, H., C. A. Hart, D. Sales, and N. B. Roberts. 2006. Bacterial killing in gastric juice-Effect of $\mathrm{pH}$ and pepsin on Escherichia coli and Helicobacter pylori. J. Med. Microbiol. 55:1265-1270. 